DOI 10.31558/2307-2318.2018.4.8

УДК 331.2:352.07 (100)

Подлужна Н.О., к.е.н., доцент, доцент кафедри менеджменту і державного управління, ДВНЗ «Донецький національний технічний університет» (м. Покровськ, Україна)

Єна Л.С., магістр, ДВНЗ «Донецький національний технічний університет» (м. Покровськ, Україна)

\title{
ТРАНСФОРМАЦІЯ ОРГАНІЗАЦІЇ ОПЛАТИ ПРАЦІ ПЕРСОНАЛУ ОРГАНІВ МІСЦЕВОГО САМОВРЯДУВАННЯ УКРАЇНИ НА ОСНОВІ АДАПТАЦЇ̈ ДОСВІДУ РОЗВИНЕНИХ КРАЇН СВІТУ
}

У статті досліджуються питання організації оплати праці персоналу органів місцевого самоврядування в зарубіжних країнах. Розглянуто особливості організації оплати праці органів місцевого самоврядування в Сполученому Королівстві Великої Британії та Північної Ірландії, де винагорода включає такі елементи фіксовану та додаткову заробітну плату. Виявлено, що оплата праці у Сполученому Королівстві залежить від рівня відповідальності держслужбовців та результатів. Проаналізовано систему оплати праці органів місцевого самоврядування у Франції, яка передбачає, що основна заробітна плата держслужбовців містить базову частину, матеріальну допомогу та на проживання, родинна доплату, які встановлені на законодавчому рівні. Виявлено, що винагорода органів місцевого самоврядування в Німеччині містить основну заробітну плату, яка складається з базової частини, родинна допомоги та офіційних надбавок, та додаткову, яка враховує бонуси за виконання та індивідуальні показники продуктивності праці. На основі узагальнення зарубіжного досвіду встановлено особливості організації оплати праці у зазначених країнах та запропоновано рекомендації щодо його використання в українських органах місцевого самоврядування.

Ключові слова: організація оплати праці; зарубіжний досвід; публічна служба; органи місцевого самоврядування; принцип забезпечення; оцінка результатів діяльності працівника.

\section{Подлужная Н.А., Ена Л.С. \\ ТРАНСФОРМАЦИЯ ОРГАНИЗАЦИИ ОПЛАТЫ ТРУДА ПЕРСОНАЛА ОРГАНОВ МЕСТНОГО САМОУПРАВЛЕНИЯ УКРАИНЫ НА ОСНОВЕ АДАПТАЦИИ ОПЫТА РАЗВИТЫХ СТРАН МИРА}

В статье исследуются особенности организации оплаты труда персонала органов местного самоуправления в развитых странах мира. Рассмотрены особенности организации оплаты труда персонала органов местного самоуправления в Соединенном Королевстве Великобритании и Северной Ирландии, где вознаграждение включает основную и дополнительную заработную плату. Выявлено, что оплата труда в Соединенном Королевстве зависит от уровня ответственности госслужащего и результатов его деятельности. Проанализирована организация оплаты труда персонала органов местного самоуправления во Франции, которая состоит из: основной заработной платы, предусматривающей базовую заработную плату, пособие на проживание, семейную доплату к заработной плате, материальную помощь, и дополнительной, которая включает надбавки, учитывающие индивидуальные и коллективные результаты служащих. Определено, что в Германии основная заработная плата госслужащих включает базовую заработную плату, семейные пособия и официальные надбавки, дополнительная заработная плата - бонусы за выполнение и производительность. На 
основе систематизации опыта об особенностях организации оплаты труда госслужащих предложены рекомендации, которые можно использовать в условиях деятельности украинских органов местного самоуправления.

Ключевые слова: организация оплаты труда; зарубежный опыт; публичная служба; органы местного самоуправления; принцип обеспечения; основная и дополнительная заработная плата.

\section{Podluzhna N., Yena L. \\ SHEE "Donetsk National Technical University" (Pokrovsk, Ukraine) TRANSFOMATION IN ORGANISING REMUNERATION FOR LOCAL SELF-GOVERNMENT STAFF BY ADAPTING EXPERIENCE OF DEVELOPED COUNTRIES OF THE WORLD}

The article deals with peculiarities of organizing the remuneration for local selfgovernment staff by adapting experience of developed countries of the world. Specific features of organizing the remuneration for local self-government staff in the United Kingdom of Great Britain and Northern Ireland are considered, where remuneration includes the following elements: basic salary (fixed salary) and additional ones (bonuses, extra payment). It has been found that remuneration in the United Kingdom depends on the level of responsibility and performance. The paper analyses the remuneration of local self-government bodies in France; it consists of the main salary (basic salary, welfare and accommodation assistance, and family allowance, established by the law or rules) and additional one (supplements that take into account individual and collective performance of employees). It is found that remuneration of local self-government bodies in Germany includes the following elements: basic salary (basic part, family allowances and official allowances); additional salary (performance bonuses and individual labor productivity indices). On the basis of the information provided, a summary table on the peculiarities of the organization of remuneration in the United Kingdom, France and Germany is drawn up, as well as recommendations for the Ukrainian local self-government bodies are proposed.

Key words: foreign experience; public service; local self-government bodies; remuneration; provision principle; evaluation of the employee's performance.

Постановка проблеми. Система оплати праці посадових осіб та службовців місцевого самоврядування в Україні відрізняється недостатньою прозорістю, зрозумілістю та справедливістю, що ставить під сумнів об'єктивність і неупередженість дій працівників місцевої влади, підвищує ризик корупції. Отже, досвід організації системи оплати праці органів місцевого самоврядування розвинених країн світу може бути корисним для України, використання якого дозволить забезпечити підвищення мотивації державних службовців до продуктивної праці та отримати позитивні ефекти у процесах регіонального та муніципального управління.

Аналіз останніх досліджень і публікацій. Дослідженням зарубіжного досвіду організації оплати праці публічної влади присвячено праці багатьох українських вчених. У розвідках Є.С. Чернонога розкрито особливості державної служби та організації оплати праці в зарубіжних країнах [1]. А.В. Кірмач комплексно дослідив специфічні характеристики діяльності публічної служби та встановив, що інститути державної і муніципальної служби є практично ідентичними [2]. У працях І.П. Лопушинського розкрито передовий досвід організації державної служби у Федеральній Республіці Німеччині [3]. Дослідження Н.М. Мельтюхової присвячено досвіду організації оплати праці державних службовців у Франції [4]. 
Виділення невирішеної проблеми. Але попри наявні дослідження, що присвячено визначенню особливостей оплати праці персоналу органів місцевого самоврядування у розвинених країнах світу та питанням іiі організації, залишаються не розкритими у повному обсязі з боку можливості їх використання в Україні та потребують подальшого вдосконалення.

Мета статті полягає у вдосконаленні організації оплати праці персоналу органів місцевого самоврядування в Україні на основі адаптації прогресивного досвіду розвинених країн світу.

Виклад основного матеріалу дослідження. У результаті дослідження встановлено, що існує три класичних моделі місцевого самоврядування у світі:

-англосаксонська модель, яка реалізується в умовах Сполученого Королівства Великої Британії, Північної Ірландії, Сполучених Штатів Америки, Канаді, Нової Зеландії та Австралії;

-континентальна модель, яка реалізується в умовах Франції, Італії, Швеції;

-змішана модель, яка характерна для країн Німеччини, Австрії, Японії.

На прикладі країн Сполученого Королівства Великої Британії, Франції та Німеччині, які є представниками зазначених моделей, у роботі досліджено особливості їх організації оплати праці в органах місцевого самоврядування.

Визначено, що у Сполученому Королівстві Великої Британії та Північної Ірландії відсутня письмова форма Конституції, тому у цих країнах не існує конституційного положення для місцевого самоврядування. При цьому, дії органів місцевого самоврядування регулюють Закони країн Сполученого Королівства Великої Британії та Північної Ірландії «Про місцеве самоврядування» [5].

Згідно із Законом «Про місцеве самоврядування» у Сполученому Королівстві винагорода у структурі заробітної плати держслужбовця включає такі елементи: фіксована заробітна плата; надбавки; бонуси. До того ж, крім окреслених компонентів на розмір винагороди працівника місцевого самоврядування впливають пільги у натуральній формі, на які він має право в результаті працевлаштування; збільшення або посилення прав на пенсію, якщо це є результатом рішення влади; суми, що підлягають сплаті службовцю, який перестає працювати в органах влади (розділ 8 Закону, пункт 43 (6)) [5]. Встановлено, що оплата праці в Сполученому Королівстві залежить не від стажу служби, а від рівня відповідальності посадовця та результатів його діяльності [6].

Наступним нормативно-правовим документом, який регулює питання організації заробітної плати персоналу органів місцевого самоврядування у країнах англосаксонської моделі, $є$ національна угода «Зелена книга». Вона регулює питання про оплату праці та умови надання послуг місцевого самоврядування та включає повну актуальну інформацію Національної Об'єднаної Ради 3 питань місцевого самоврядування (The National Joint Council) [7]. Національною Об'єднаною Радою 3 питань місцевого самоврядування розроблена спільна схема оцінювання роботи органів місцевого самоврядування, табл. 1. Дана схема заробітної плати діє протягом 01.04.2018 p.-31.03.2019 p.

Для заохочення працівників до особистого розвитку та покращення якості їхньої праці Рада встановила рівну іï оплату в межах рангів. Прогрес оплати праці за рангами базується на досягненні визначених цілей діяльності; поєднанні службових та цільових показників ефективності; розвитку та продуктивності тощо. Як правило, нові працівники призначаються на мінімальний рівень оплати відповідного рангу. Менеджери мають право на власний розсуд пропонувати службовця на підвищення рангу, коли він продемонстрував виняткові результати. 
Таблиця 1

Схема заробітної плати органів місцевого самоврядування у Сполученому Королівстві*

\begin{tabular}{|c|c|c|c|c|c|c|c|c|}
\hline \multirow[b]{2}{*}{ Ранг } & \multicolumn{2}{|c|}{ Основна заробітна плата } & \multirow[b]{2}{*}{ Ранг } & \multicolumn{2}{|c|}{ Основна заробітна плата } & \multirow[b]{2}{*}{ Ранг } & \multicolumn{2}{|c|}{ Основна заробітна плата } \\
\hline & $\begin{array}{c}\text { За рік, } \\
\text { фунтів } \\
\text { стерлінгів }\end{array}$ & $\begin{array}{c}\text { Погодинна } \\
\text { ставка**, } \\
\text { фунтів } \\
\text { стерлінгів }\end{array}$ & & $\begin{array}{c}\text { За рік, } \\
\text { фунтів } \\
\text { стерлінгів }\end{array}$ & $\begin{array}{l}\text { Погодинна } \\
\text { ставка**, } \\
\text { фунтів } \\
\text { стерлінгів }\end{array}$ & & $\begin{array}{c}\text { За рік, } \\
\text { фунтів } \\
\text { стерлінгів }\end{array}$ & $\begin{array}{c}\text { Погодинна } \\
\text { ставка**, } \\
\text { фунтів } \\
\text { стерлінгів }\end{array}$ \\
\hline 6 & 16394 & 8,50 & 21 & 20541 & 10,65 & 36 & 32233 & 16,71 \\
\hline 7 & 16495 & 8,55 & 22 & 21074 & 10,92 & 37 & 33136 & 17,18 \\
\hline 8 & 16626 & 8,62 & 23 & 21693 & 11,24 & 38 & 34106 & 17,68 \\
\hline 9 & 16755 & 8,68 & 24 & 22401 & 11,61 & 39 & 35229 & 18,26 \\
\hline 10 & 16863 & 8,74 & 25 & 23111 & 11,98 & 40 & 36153 & 18,87 \\
\hline 11 & 17007 & 8,82 & 26 & 23866 & 12,37 & 41 & 37107 & 19,23 \\
\hline 12 & 17173 & 8,90 & 27 & 24657 & 12,78 & 42 & 38052 & 19,72 \\
\hline 13 & 17391 & 9,01 & 28 & 25463 & 13,20 & 43 & 39002 & 20,22 \\
\hline 14 & 17681 & 9,16 & 29 & 26470 & 13,72 & 44 & 39961 & 20,71 \\
\hline 15 & 17972 & 9,32 & 30 & 27358 & 14,18 & 45 & 40858 & 21,18 \\
\hline 16 & 18319 & 9,50 & 31 & 28221 & 14,63 & 46 & 41846 & 21,69 \\
\hline 17 & 18672 & 9,68 & 32 & 29055 & 15,06 & 47 & 42806 & 22,19 \\
\hline 18 & 18870 & 9,78 & 33 & 29909 & 15,50 & 48 & 43757 & 22,68 \\
\hline 19 & 19446 & 10,08 & 34 & 30756 & 15,94 & 49 & 44697 & 23,17 \\
\hline 20 & 19819 & 10,27 & 35 & 31401 & 16,28 & & & \\
\hline
\end{tabular}

*Складено на основі даних «Зеленої книги» Національної угоди [8, с. 223-224]

**Розраховано з урахування показників річного заробітку, кількості днів у роиі, кількості робочих тижнів (52,143 тижня на рік), кількості годин протягом робочого тижня (37 годин)

Під час процесів визначення обсягу заробітної плати у країнах, які відносяться до англосаксонської моделі, можна корегувати особливі надбавки чи надбавки окремим працівникам у рамках їх трудового договору, якщо цього вимагають конкретні обставини та не заперечено політикою ради. Такі надбавки узгоджуються на національному або місцевому рівнях шляхом узгодження колективних переговорів та (або) визначаються політикою Ради [9, с. 17-18].

До того ж, встановлено, що в інтересах ясності та прозорості в оплаті праці, Національна Об'єднана Рада наполегливо пропонує місцевим органам влади використовувати можливість організації загальної стратегії винагороди, не обмежуючись тільки питаннями, які конкретно вимагає Закон «Про місцеве самоврядування» та інші нормативні акти [10, с. 5].

Наступну континентальну модель місцевого самоврядування досліджено на прикладі Франції, територіальна державна служба якої заснована у 1984 р. та є третім органом державної служби поряд 3 центральною і лікарняною службами. Органи територіальної державної служби, головним чином, регулюються Законом Франції № 8453 від 26 січня 1984 р. «Про встановлення нормативних положень стосовно територіальної державної служби» та його положеннями про здійснення [11].

Згідно 3 цим Законом, винагорода органів територіальної державної служби встановлена відповідно до положень статті 20 розділу I Закону № 83-634 від 13 липня 1983 р. «Про права та обов'язки державних службовців» [12]. Відповідно з цим законом державні службовці мають право на винагороду, яка складається 3 таких елементів: базова заробітна плата; допомога на проживання; родинна доплата; матеріальна допомога, встановлена законом або правилами; надбавки, які враховують індивідуальні та колективні результати службовців. 
Розмір базової заробітної плати у Франції визначається відповідно до рангу держслужбовця, рівня його досягнень або посади. Залежно від рангу, який пов'язується з валовим індексом, визначається його позиція відповідно до загальної шкали індексів, яка використовується для всіх категорій державних службовців органів місцевого самоврядування. Таким чином, місячна базова заробітна плата державного службовця розраховується шляхом множення значення індексної точки, яка 3 01.02.2017 p. оцінюється у розмірі 4,69 євро, на валовий індекс, який відповідає його рангу [13].

Наступна частина винагороди за працю державних службовців Франції - допомога на проживання, що надається посадовим особам, заробітна плата яких враховує «прикріплений індекс державної служби» [13]. Ця допомога розраховується на підставі розміру заробітної плати державного службовця, яка підлягає стягненню пенсійних внесків, відповідно до ставок, наведених в Розпорядженні № 85-1148 від 24 жовтня 1985 р. До того ж родинна доплата, яка $\epsilon$ також частиною заробітної плати державних службовців Франції, залежить від кількості дітей у сім’ї та може бути представлена у вигляді щомісячної фіксованої суми або розраховуватися як відсоток до заробітної плати [14].

Отже, така система оплати праці персоналу органів місцевого самоврядування Франції передбачає, що державні службовці однакового рівня отримують однакову основну винагороду в межах одного рангу незалежно від якості їхньої індивідуальної роботи. Це глобальна система, в якій кожна група пов'язана з оплатою всіх інших груп [15, с. 14]. При цьому індивідуальна винагорода відображає специфічні труднощі роботи або понаднормові роботи, а також залежить від заслуг, відданості та досвіду кожного службовця. У Франції виплати додаткової заробітної плати розпочато після впровадження системи компенсацій $з$ урахуванням функцій, обмежень, досвіду та професійної відповідальності держслужбовців (Régime indemnitaire tenant compte des fonctions, des sujétions, de l'expertise et de l'engagement professionnel, RIFSEEP) [16]. Таким чином, встановлено, що структура середньої оплати праці службовців територіальної державної служби має таку структуру: 67\% складає основна заробітна плата, 33\% додаткова заробітна плата.

Наступної країною, досвід щодо організації оплати праці держслужбовців якої досліджено, $\epsilon$ Німеччина. Вона $є$ представником змішаної моделі оплати праці персоналу органів публічної влади, яка регулюється Основним законом (Grundgesetz) від 23 травня 1949 р., згідно з яким місцеві питання вирішуються самостійно органами місцевого самоврядування. Основний закон визначає принцип єдності статусу державних службовців, незалежно від того, служать вони федерації, територіям чи місцевому самоврядуванню [17].

Досліджено, що місцеві органи влади Німеччини мають дві категорії персоналу:

-державні службовці, які керуються кар'єрною системою і в основному займають посади в традиційному управлінні;

- працівники, які працюють за позиційними системами та контрактом, але їх статус фактично забезпечує їм однакову безпеку з державними службовцями.

У Німеччині оплата праці державних службовців грунтується на принципі забезпечення, який є одним з конституційних принципів професійної державної служби. Згідно 3 цим принципом роботодавець зобов'язаний забезпечити підтримку, яка відповідає призначеній посаді, якщо державні службовці стають непрацездатними чи досягають пенсійного віку. Винагорода призначена для того, щоб державні службовці могли повністю присвятити себе своїм обов'язкам, адже тільки фінансово незалежна державна служба здатна виконувати свої конституційні функції [18, с. 82]. 
Винагорода державних службовців регулюється Законом Німеччини «Про винагороду державних службовців» (Bundesbesoldungsgesetz), відповідно 3 яким винагорода державних службовців, яка виплачується щомісячно, складається 3 п'яти частин: базової заробітної плати; родинної допомоги, за винятком збільшення для рангів А2-А5; офіційних надбавок; бонусів за виконання та продуктивність [19].

Основна заробітна плата є основним елементом винагороди і складає близько $85 \%$ сукупного доходу державного службовця. Вона заснована на рангах відповідно категорії посад та не залежить від того, яку функцію фактично виконує державний службовець $[18$, c. 82$]$.

До того ж у Німеччині існує чотири схеми винагороди - схем A, B, W та R. Схеми A та В регулюють винагороду державних службовців та військовослужбовців, схема $\mathrm{W}$ - професорсько-викладацький склад у закладах вищої освіти, а схема $\mathrm{R}$ - суддів та прокурорів [20, с. 5]. Схема заробітної плати А включає в себе декілька категорій посад державних службовців, яким відповідають конкретні ранги. Схема В передбачає врахування особливостей оплати праці держслужбовців рангів В1-В11. При цьому, державні службовці, яким виплачують основну заробітну плату за схемою А (переважна більшість всіх державних службовців), отримують додаткові заробітні плати, тоді як державні службовці, яким оплачують заробітну плату за схемою В, отримують тільки фіксовані заробітні плати [20, с. 6].

Найвищий ранг найнижчої категорії посади зазвичай $\epsilon$ початковим рангом наступної категорії посади. Державний службовець, який має задовільні показники протягом певного періоду служби, переходить до наступного рангу. Необхідна тривалість служби для переходу на наступний етап спочатку складає два роки, а потім збільшується до трьох-чотирьох років. Це враховує той факт, що досвід набирає швидкості на початку кар'єри. Державні службовці, які мають професійний досвід у державній службі і за ії межами та додаткову кваліфікацію можуть розпочати на більш високому рівні [18, с. 83$]$.

Отже, у Німеччині визначено схеми нарахування заробітних плат А та В, термін дії яких передбачено з 01.03.2018 р. до 31.03.2019 р., табл. 2-3 [21].

Таблиця 2

Схема нарахування заробітної плати А держаних службовців Німеччини*

\begin{tabular}{|c|c|c|c|c|c|c|c|c|}
\hline \multirow{2}{*}{ Ранг } & \multicolumn{7}{|c|}{ Основна заробітна плата (щомісячні суми, свро) } \\
\cline { 2 - 10 } & Етап 1 & Етап 2 & Етап 3 & Етап 4 & Етап 5 & Етап 6 & Етап 7 & Етап 8 \\
\hline А 2 & 2127,35 & 2174,74 & 2223,41 & 2259,88 & 2297,58 & 2335,28 & 2372,96 & 2410,66 \\
\hline A 3 & 2208,82 & 2258,66 & 2308,51 & 2348,65 & 2388,77 & 2428,89 & 2469,03 & 2509,15 \\
\hline А 4 & 2255,04 & 2314,60 & 2374,18 & 2421,60 & 2469,03 & 2516,45 & 2563,86 & 2607,65 \\
\hline A 5 & 2272,03 & 2346,20 & 2405,77 & 2464,17 & 2522,54 & 2582,13 & 2640,48 & 2697,63 \\
\hline А 6 & 2320,67 & 2407,03 & 2494,55 & 2561,43 & 2630,75 & 2697,63 & 2771,80 & 2836,25 \\
\hline А 7 & 2436,20 & 2512,81 & 2613,76 & 2717,08 & 2818,01 & 2920,16 & 2996,77 & 3073,37 \\
\hline A 8 & 2577,25 & 2669,68 & 2799,77 & 2931,12 & 3062,42 & 3153,62 & 3246,04 & 3337,24 \\
\hline А 9 & 2781,52 & 2872,73 & 3016,23 & 3162,14 & 3305,60 & 3403,13 & 3504,60 & 3603,54 \\
\hline А 10 & 2977,30 & 3102,54 & 3283,74 & 3465,74 & 3651,12 & 3780,14 & 3909,13 & 4038,18 \\
\hline А 11 & 3403,13 & 3594,76 & 3785,15 & 3976,78 & 4108,29 & 4239,81 & 4371,33 & 4502,87 \\
\hline А 12 & 3648,64 & 3875,34 & 4103,30 & 4329,99 & 4487,82 & 4643,12 & 4799,69 & 4958,77 \\
\hline А 13 & 4278,65 & 4491,58 & 4703,24 & 4916,18 & 5062,73 & 5210,53 & 5357,06 & 5501,10 \\
\hline А 14 & 4400,14 & 4674,43 & 4950,00 & 5224,29 & 5413,41 & 5603,82 & 5792,94 & 5983,34 \\
\hline А 15 & 5378,35 & 5626,37 & 5815,48 & 6004,63 & 6193,77 & 6381,64 & 6569,52 & 6756,13 \\
\hline А 16 & 5933,22 & 6221,33 & 6439,25 & 6657,19 & 6873,89 & 7093,09 & 7311,02 & 7526,46 \\
\hline
\end{tabular}


Таблиця 3

Схема нарахування заробітної плати держаних службовців Німеччини*

\begin{tabular}{|c|c|c|c|}
\hline Ранг & $\begin{array}{c}\text { Основна заробітна плата } \\
\text { (щомісячні суми, євро) }\end{array}$ & Ранг & $\begin{array}{c}\text { Основна заробітна плата } \\
\text { (щомісячні суми, євро) }\end{array}$ \\
\hline B 1 & 6756,13 & B 7 & 10384,73 \\
\hline B 2 & 7848,36 & B 8 & 10917,03 \\
\hline B 3 & 8310,52 & B 9 & 11577,13 \\
\hline B 4 & 8794,00 & B 10 & 13627,52 \\
\hline B 5 & 9348,89 & B 11 & 14157,33 \\
\hline В 6 & 9876,22 & & \\
\hline \multicolumn{2}{|c}{} \\
*кладено на основі [21]
\end{tabular}

Наступною частиною заробітної плати персоналу органів самоврядування Німеччини є родинна допомога, яка $є$ частиною винагороди, що враховує додатковий тягар, та пов'язана із наявністю у сім'ї дітей порівняно 3 іншими державними службовцями.

Визначено, що офіційні надбавки також входять до основної винагороди, яка враховує конкретні вимоги та досягнення. Надбавки можуть бути наступних видів: функціональні; посадові; за труднощі; компенсаційні за переведення до федеральної служби; понаднормова оплата [18, с. 82-90].

Крім основної винагороди державні службовці, яким виплачують заробітну плату за схемою А, можуть отримувати бонуси та доплати за продуктивність та видатні особливі досягнення. Ці інструменти оплати праці призначені для винагородження видатних досягнень, підвищення мотивації та продуктивності та не можуть складати більше 15\% від загальної винагороди [19].

У результаті дослідження зроблено узагальнення зарубіжного досвіду організації оплати праці на прикладі країн Сполученому Королівстві, Франції та Німеччині, які є представниками англосаксонської, континентальної та змішаної моделей, та запропоновано пропозиції щодо його використання в органах місцевого самоврядування України, табл. 4-5.

Таблиця 4

Особливості організації системи оплати праці персоналу органів місцевого самоврядування у Сполученому Королівстві, Франції та Німеччині*

\begin{tabular}{|c|c|c|c|}
\hline Критерії оцінки & $\begin{array}{c}\text { Сполучене } \\
\text { Королівство } \\
\text { Великої Британії та } \\
\text { Північної Ірландії } \\
\end{array}$ & Франція & Німеччина \\
\hline $\begin{array}{l}\text { Структура } \\
\text { заробітної плати, } \\
\text { у т.ч. } \\
\text { основної }\left(3_{\text {пл-о }}\right)\end{array}$ & $\begin{array}{c}\text { базова заробітна } \\
\text { плата }\end{array}$ & $\begin{array}{c}\text { базова заробітна плата, } \\
\text { допомога на проживання, } \\
\text { родинна доплата до заробітної } \\
\text { плати, матеріальна допомога }\end{array}$ & $\begin{array}{c}\text { базова заробітна плата, } \\
\text { родинна допомога та } \\
\text { офіційні надбавки }\end{array}$ \\
\hline $\begin{array}{l}\text { додаткової } \\
\left(3_{n л-\partial}\right)\end{array}$ & надбавки, бонуси & $\begin{array}{c}\text { надбавки, які враховують } \\
\text { індивідуальні та колективні } \\
\text { результати } \\
\end{array}$ & $\begin{array}{c}\text { бонуси за виконання та } \\
\text { продуктивність праці }\end{array}$ \\
\hline $\begin{array}{l}\text { Співвідношення } \\
3_{n л-о ~} \text { та } 3_{n л-д}\end{array}$ & $80 / 20$ & $67 / 33$ & $85 / 15$ \\
\hline
\end{tabular}

*Складено та розраховано на основі $[5 ; 6 ; 10$, с. $5 ; 12 ; 13 ; 19]$ 
Пропозиції щодо удосконалення організації оплати праці в органах місцевого самоврядування України на основі досвіду розвинених країн світу

\begin{tabular}{|c|c|}
\hline Країна & $\begin{array}{c}\text { Елементи механізму організації оплати праці, які пропонується впровадити в діяльність } \\
\text { українських органів місцевого самоврядування }\end{array}$ \\
\hline $\begin{array}{l}\text { Сполучене } \\
\text { Королівство } \\
\text { Великої } \\
\text { Британї̈ та } \\
\text { Північної } \\
\text { Ірландії }\end{array}$ & $\begin{array}{l}\text { 1.Використання механізму оплати праці залежно від відповідальності державного } \\
\text { службовця. } \\
\text { 2.Внесення змін до нормативно-законодавчої бази України щодо надання ширших } \\
\text { повноважень Асоціації органів місцевого самоврядування, яка буде представляти } \\
\text { місцеву владу в Україні та її працівників, що може забезпечити достатню гнучкість для } \\
\text { реагування на проблеми, з якими вони стикаються. Для побудови ефективної системи } \\
\text { оплати праці надати можливість вносити зміни до існуючої системи оплати праці } \\
\text { посадових осіб та службовців місцевого самоврядування, що не буде суперечити законам } \\
\text { та розпорядженням. } \\
\text { 3.Забезпечення наявності взаємозв’язків між показниками продуктивності праці та } \\
\text { структурними елементами заробітної плати [22, с. 9]. При цьому, основна заробітна плата } \\
\text { та гарантовані пільги повинні складати більшу частину загальної винагороди, що } \\
\text { допоможе компетентному персоналу почувати себе в безпечному становищі }\end{array}$ \\
\hline & 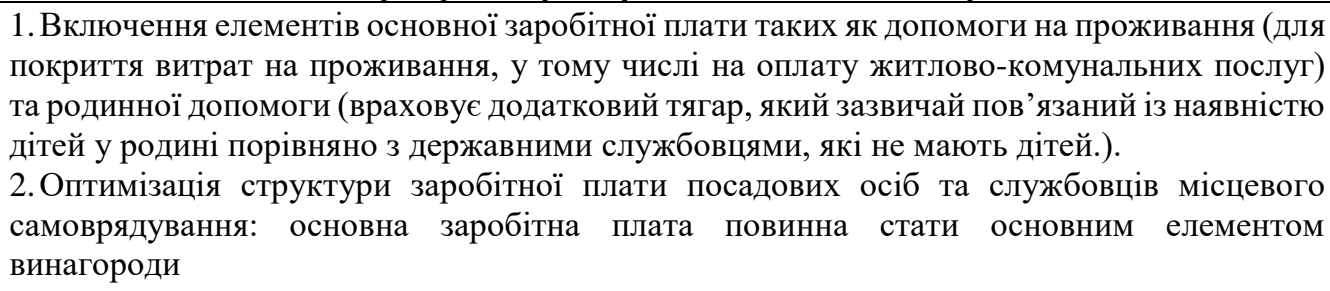 \\
\hline Німеччина & $\begin{array}{l}\text { 1. Оптимізація структури заробітної плати посадових осіб та службовців місцевого } \\
\text { самоврядування: основна заробітна плата повинна стати основним елементом } \\
\text { винагороди, яка призначена для того, щоб державні службовці могли повністю } \\
\text { присвятити себе своїм обов'язкам, адже тільки фінансово незалежні посадові особи та } \\
\text { службовці місцевого самоврядування здатні виконувати свої функції в повну силу }\end{array}$ \\
\hline
\end{tabular}

*3апропоновано на основі $[5 ; 6 ; 12 ; 22$, с. 9]

Отже, з урахуванням запропонованих пропозицій щодо вдосконалення механізму організації оплати праці персоналу органів місцевого самоврядування на основі дослідження досвіду розвинених країн світу, необхідно впровадити наступні заходи:

- змінити співвідношення обсягів основної (посадовий оклад та постійні надбавки) та додаткової (додаткові стимулюючі виплати та премії) заробітної плати, тобто запровадити систему оплати праці, яка буде прозора та зрозуміла як громадянам, так і органам місцевого самоврядування, рис. 1;

- збільшити посадовий оклад службовцям для забезпечення належної винагороди з урахуванням складності виконуваних робіт, а також збереження стимулу до покращення надання суспільних послуг, табл. 6;

- додати до постійних надбавок родинну доплату та доплату на проживання. При цьому, надбавку за ранг пропонується виключити із переліку надбавок, тому що новий посадовий оклад вже враховує ранг службовця;

- удосконалити процедуру оцінки результатів діяльності персоналу для призначення стимулюючих надбавок та премії.

Отже, зміна структури оплати праці персоналу в органах місцевого самоврядування буде сприяти підвищенню конкурентоспроможності державної служби порівняно 3 роботодавцями приватного сектору на ринку праці, залучення кваліфікованого та компетентного персоналу до працевлаштування, зменшенню дії загроз для забезпечення кадрової безпеки організацій [23, с. 164]. 


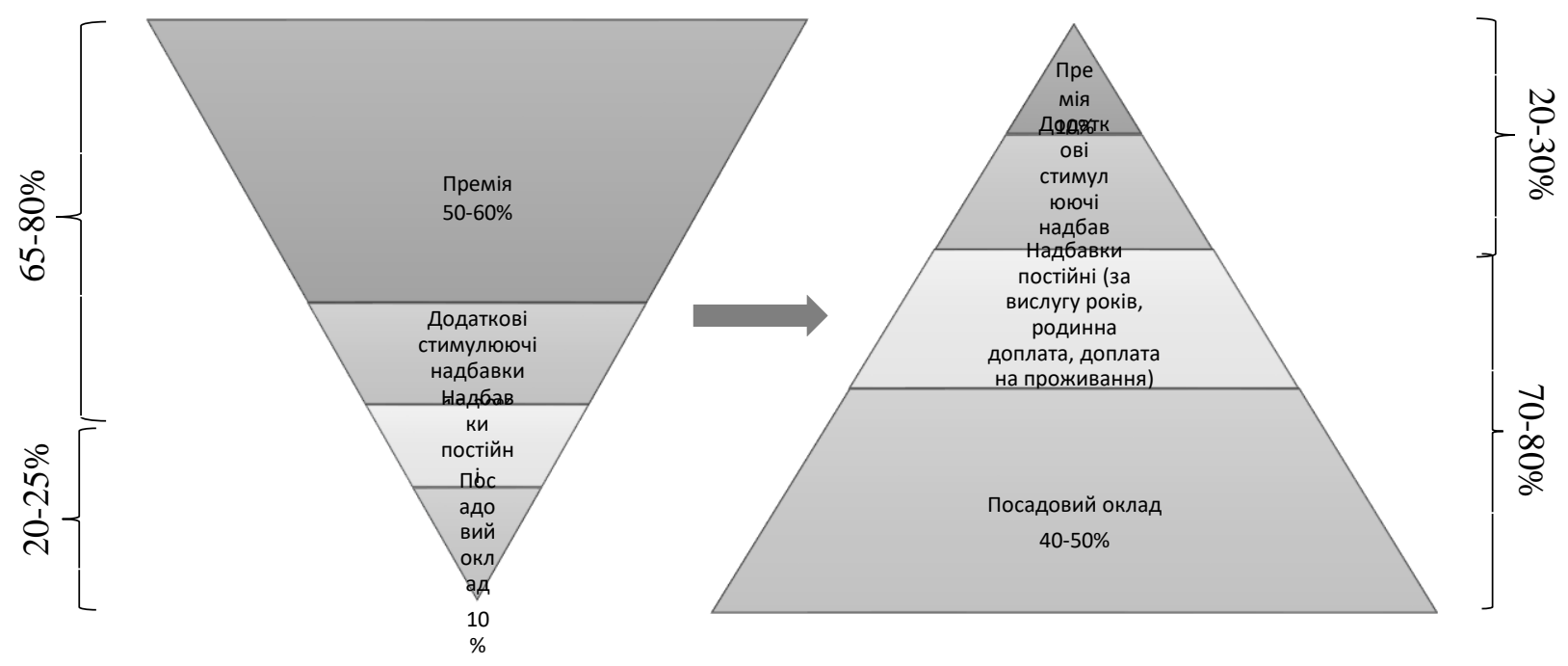

Рисунок 1 - Поточна та перспективна структури оплати праці персоналу органів місцевого самоврядування

Таблиця 6

Схема посадових окладів держслужбовців органів місцевого самоврядування*

\begin{tabular}{|c|c|c|c|c|c|c|c|c|c|}
\hline Категорія посади & \multicolumn{3}{|c|}{4} & \multicolumn{2}{|l|}{5} & \multicolumn{2}{|l|}{6} & \multicolumn{2}{|l|}{7} \\
\hline Ранг & 7 & 8 & 9 & 10 & 11 & 12 & 13 & 14 & 15 \\
\hline $\begin{array}{c}\text { Посадовий оклад, } \\
\text { грн }\end{array}$ & 10300 & 9800 & 9300 & 8800 & 7700 & 6600 & 5800 & 5400 & 5000 \\
\hline
\end{tabular}

*3апропоновано авторами

Отже, розмір родинної доплати повинен бути частиною основної заробітної плати держслужбовців України. При цьому, родинна доплата представлена у вигляді щомісячної фіксованої суми, яка залежить від кількості дітей у сім'ї: 1 дитина - розмір щомісячної родинної надбавки пропонується 20\%; 2 і більше дитини - 30\% від рівня прожиткового мінімуму для дітей відповідного віку в Україні.

До того ж доцільно, щоб доплата на проживання теж стала частиною основної винагороди держслужбовців та була призначена для компенсації вартості комунальних послуг для персоналу, який мешкає у квартирах, або загальної вартості вугілля, яке необхідно на опалювальний сезон для персоналу, що мешкає у власних будинках.

Впровадження елементів оплати праці, які враховують результати діяльності працівника (performance-related pay), сприяє індивідуальній мотивації, покращує імідж та зміцнює внутрішній та зовнішній бренд державної служби, підвищує можливість ефективно конкурувати 3 приватним сектором щодо залучення кваліфікованого та компетентного персоналу [24, с. 3].

Висновки та перспективи подальших досліджень. На основі досвіду розвинених країн світу, було запропоновано рекомендації щодо удосконалення організації оплати праці в органах місцевого самоврядування України. Обгрунтовано внесення змін до нормативно-законодавчої бази України щодо надання більш широких повноважень Асоціації органів місцевого самоврядування. До того ж пропонується оптимізувати структуру заробітної плати за рахунок збільшення посадових окладів службовцям та включення до основної іiі частини допомогу на проживання та родинну 
допомогу. Для підвищення мотивації держслужбовців до праці доцільно удосконалити процедуру оцінки результатів їх діяльності з метою призначення стимулюючих надбавок та премії. Подальшим напрямом наукових досліджень $є$ визначення особливостей організації оплати праці держслужбовців в умовах впровадження електронного врядування.

\section{СПИСОК ВИКОРИСТАНИХ ДЖЕРЕЛ}

1. Чорноног Є.С. Державна служба: історія, теорія і практика / С.С. Чорноног. - Київ: Знання, 2008. - 458 с.

2. Кірмач А.В. Публічна служба : зарубіжний досвід та пропозиції для України / А. В. Кірмач, В.П. Тимощук, А. М. Школик. - Київ: Конус-Ю, 2007. - 735 с.

3. Лопушинський I.П. Публічна служба Німеччини: досвід для України / I. П. Лопушинський. // Публічне управління: теорія та практика. - 2011. - № 4 (8). - С. 48-54. 4. Мельтюхова Н.М. Зарубіжний досвід публічного адміністрування / Н. М. Мельтюхова, В. В. Корженко, Ю. В. Дідок. - Київ: НАДУ, 2010. - 28 с.

5. The Localism Act. 2011 [Електронний pecypc]. - Режим доступу до ресурсу: http://www.legislation.gov.uk/ukpga/2011/20/contents/enacted.

6. Ministère du Budget, des Comptes publics et de la Fonction publique. Administration and the civil service in the EU 27 member states: 27 country profiles / Ministère du Budget, des Comptes publics et de la Fonction publique., 2008.

7. Local Government Association [Електронний ресурс] - Режим доступу до ресурсу: https://www.local.gov.uk/.

8. National Joint Council for local government services National Agreement on Pay and Conditions of Service, 2018. -225 c.

9. Local Government Association. Pay Policy and Practice in Local Authorities - A guide for Councillors / Local Government Association., 2013. - 28 c.

10. Joint Negotiating Committee for Youth and Community Workers: Staff Side Pay and Conditions Claim 2018. Submitted by Unite, Unison, NEU and UCU, 2018. - 18 c.

11. Loi ${ }^{\circ} 84-53$ du 26 janvier 1984 portant dispositions statutaires relatives à la fonction publique territoriale [Електронний pecypc] - Режим доступу до ресурсу: https://www.legifrance.gouv.fr/affichTexte.do?cidTexte=JORFTEXT000000320434\&fastPos $=1 \&$ fastReqId $=225940823 \&$ categorieLien $=$ cid $\&$ oldAction $=$ rechTexte\#LEGISCTA00000608 6319.

12. Loi $\mathrm{n}^{\circ} 83-634$ du 13 juillet 1983 portant droits et obligations des fonctionnaires. Loi dite loi Le Pors [Електронний pecypc] - Режим доступу до ресурсу: https://www.legifrance.gouv.fr/affichTexte.do?cidTexte=JORFTEXT000000504704\&fastPos =4\&fastReqId=297666419\&categorieLien=cid\&oldAction=rechTexte\#LEGIARTI00002244 7018.

13. Le portail de la Fonction publique [Електронний ресурс] - Режим доступу до ресурсу: https://www.fonction-publique.gouv.fr/connaitre-point-dindice.

14. REPUBLIC OF FRANCE: Public Administration Country Profile. Submitted by Division for Public Administration and Development Management (DPADM), Department of Economic and Social Affairs (DESA), United Nations, 2006. - 22 c.

15. Le portail de l'Etat au service des collectivités [Електронний ресурс] - Режим доступу до ресурсу: https://www.collectivites-locales.gouv.fr/remunerations.

16. Indemnité RIFSEEP, où en est-on? [Електронний ресурс] // UNSA Education. - 2017.

- Режим доступу до ресурсу: http://www.unsa-education.com/spip.php?article2067. 
17. Grundgesetz für die Bundesrepublik Deutschland [Електронний ресурс] - Режим доступу до ресурсу: http://www.gesetze-im-internet.de/gg/index.html.

18. The federal public service: An attractive and modern employer - Berlin: Federal Ministry of the Interior, 2014. - $120 \mathrm{c}$.

19. Bundesbesoldungsgesetz [Електронний ресурс] - Режим доступу до ресурсу: http://www.gesetze-im-internet.de/bbesg/index.html.

20. Otto K. Civil Service Salary System in Germany And Recent Reform Trends. Conference on Civil Service Salary Systems in Europe / Kai-Andreas Otto. - Berlin, Germany: OECD, 2007. - $10 \mathrm{c}$.

21. Beamtenbesoldung - Besoldung [Електронний ресурс] - Режим доступу до ресурсу: https://www.beamtenbesoldung.org.

22. Hutton W. Hutton review of fair pay in the public sector: final report / Will Hutton., 2011. $-128 \mathrm{c}$.

23. Подлужна Н.О. Кількісна оцінка кадрової безпеки організації // Вісник Донецького Національного Університету. Серія Економіка і право. - 2011. - Вип. 2. - С. 160-164.

24. Blum J. Performance-related pay policies for government employees: an overview of OECD countries / Jürgen René Blum// OECD. - 2006. - C. 11. 